\title{
TCF3/PBX1 Fusion Gene
}

National Cancer Institute

\section{Source}

National Cancer Institute. TCF3/PBX1 Fusion Gene. NCI Thesaurus. Code C99291.

A fusion gene that results from a chromosomal translocation $\mathrm{t}(1 ; 19)(q 23 ; \mathrm{p} 13)$ which fuses intron 13 of the TCF3 gene with exon 2 of the PBX1 gene. This rearrangement is associated with pre-B cell acute lymphoblastic leukemia. 